\title{
Tax Neutralization in Employment Cases Comes to California: Clemens and Economy
}

\author{
Barry Ben-Zion \\ Consulting Forensic Economist
}

This paper is designed to explain the concept of tax neutralization as it applies to non-physical injury legal cases and to describe the two legal cases that brought acceptance of this concept to all California courts.

Keywords: Non-Physical Injury Legal Cases, Adverse Tax Consequence, Tax Neutralization, 9th Circuit Court of Appeal, California Courts

\section{INTRODUCTION}

The U.S. Congress, back in1996, clarified that any award or settlement in a physical injury or a death case would not be subject to Federal income taxes, but, that any award or settlement in non-physical injury case would be subjected to said tax in the year in which it is paid. The act, H.R. 3448, known as the Small Business Job Protection Act of 1996, further clarified that emotional distress would not be considered a physical injury. The Internal Revenue Service applies this standard. ${ }^{1}$

Employment cases, whether termination, discrimination, or wage and hour cases, are non-physical injury cases. The same is true for a variety of other legal cases, such as business damage cases and other non-physical disputes.

Due to the progressive nature of Federal income taxes as well as income taxes of many states, a lump sum award or settlement of a legal case will likely be taxed at a higher rate than the rate that would have applied to sequential annual losses. The result is that the plaintiff will suffer an adverse tax consequence from the application of the higher tax rates to the lump sum and would not be made whole unless the adverse tax consequence is neutralized. The amount needed to neutralize the adverse tax consequence is referred to herein as the "tax neutralization amount."

Subsequent to the passage of H.R. 3448, academic articles began to appear in the forensic economic literature to illustrate the concept of the adverse tax consequence of a lump sum award and the amount needed to neutralize it. ${ }^{3}$

One of the earliest Federal Court legal case which specifically awarded an additional amount to cover the adverse tax consequence was Richard P. O'Neal v. Sears, Roebuck and Co. ${ }^{4}$ Legal literature followed. ${ }^{5}$

All academic articles in the forensic economic literature which appeared after the year 2000 agree that a tax neutralization adjustment is appropriate. No academic paper has ever appeared to suggest that the concept is inappropriate or illogical. ${ }^{6}$ 
This paper demonstrates the concepts of the adverse tax consequence of a lump sum award and the tax neutralization amount. It then discusses the two appellate decisions that brought about a legal acceptance of the concept of tax neutralization to both Federal and State courts in California, i.e., the Clemens case, ${ }^{7}$ which applies to all federal courts in the Ninth Circuit, and the Economy case which applies to State of California superior courts.

\section{ILLUSTRATION OF THE TAX NEUTRALIZATION CONCEPT}

A simplified illustration would help the reader comprehend the difference between the adverse tax consequence and the tax neutralization concepts.

Assume that an employee is wrongfully terminated and that as a result he lost $\$ 100,000$ per year for a period of 5 years. The total loss adds up to $\$ 500,000$. Assume further that, had the employee earned his annual income sequentially, that his annual tax burden would have been 20 percent, or $\$ 20,000$ per year. Thus, if the employee had not lost his job, he would have earned $\$ 500,000$, paid $\$ 100,000$ in taxes $(\$ 20,000 \times 5)$. The employee's after-tax income would have been $\$ 80,000$ per year, or a total net income of $\$ 400,000$.

If the employee is awarded $\$ 500,000$ for his lost earnings, the award would be subject to taxes in a single year. Assume that the total tax burden would be 40 percent. The employee would have to pay $\$ 200,000$ in taxes and receive an after-tax award of only $\$ 300,000$.

The adverse tax consequence of receiving a lump sum award is $\$ 100,000$ ( $\$ 200,000$ in taxes on the lump sum award versus $\$ 100,000$ in sequential taxes, or, alternatively, $\$ 400,000$ in after-tax income sequentially versus $\$ 300,000$ in after-tax income given the lump sum). Clearly, the lump sum award of $\$ 500,000$ would not make the terminated employee whole.

To be made whole, the employee would have to receive an additional award that would result in increasing his after-tax lump sum by $\$ 100,000$. But since any additional award would also be taxed at high tax rates, the additional amount needed to be paid to neutralize the adverse tax consequence is greater than $\$ 100,000$. If the highest marginal tax rate is capped at 40 percent, the tax neutralization amount would have to be $\$ 166,667$. In other words, the total award would have to be $\$ 666,667$ (\$500,000 $+\$ 166,667)$ to insure that the terminated employee receive an after-tax lump sum of $\$ 400,000$, the exact result that would have occurred had the terminated employee earned the income sequentially, i.e., be made whole.

The actual calculation of the adverse tax consequence and tax neutralization is more complicated than the simple illustration presented above. The calculation in a specific case requires that all taxes of employment earnings be considered. This is true for the taxes on the lump sum award. One needs to consider the federal income taxes, the state income taxes (if applicable), city income taxes (if applicable), the social security taxes, the Medicare taxes, the state disability taxes, and any other employment base taxes that are applicable in the jurisdiction in question.

If post termination the employee secured alternative employment and partially mitigated his loss of earnings, then the sequential taxes would have to be calculated for both the projected earning absent the termination and the earnings given the termination. The difference between these two magnitudes is the extra taxes (or the marginal taxes) that would have been paid for the additional income that is claimed to be lost. The marginal sequential taxes would then have to be compared to the marginal taxes payable on the lump sum award to arrive at the adverse tax consequence that would have to be neutralized.

\section{CASE LAW APPLICABLE TO FEDERAL AND STATE COURTS IN CALIFORNIA}

Economists and other financial experts have testified to the concept of tax neutralization in various federal and state courts in California and other Ninth Circuit states for many years. ${ }^{8}$ But no one had appealed the issue in either the Ninth Circuit until the Clemens case, and no one had ever appealed it in the state court in California till the Economy case. ${ }^{9}$ 
This author is aware of at least one case that was appealed in the state court of Washington, a state that is part of the Ninth Circuit. This is the Blaney case. ${ }^{10}$ In said case, the Court of Appeal, and later the Washington Supreme Court, approved the extra award to neutralize the adverse tax consequence of the lump sum award. But a state of Washington case is not applicable in the state courts of California.

\section{The Clemens Case}

The Clemens case was a Title VII case (i.e., an employment discrimination case). The District Court denied the adjustment for tax neutralization on the grounds that the Ninth Circuit has never previously considered it. Plaintiff appealed. The Ninth Circuit issued its decision in November 2017. The Ninth Circuit decision is illuminating, as it discusses the relevant decisions of other Circuits.

The Third Circuit approved the discretion of the District Court to "gross up" an award to account of income-tax consequences in the Eshelman v. Agere Sys.case. ${ }^{11}$ The Seventh Circuit approved it in EEOC v. N. Star Hospital. ${ }^{12}$ The Tenth Circuit approved it in Sears v. Atchison. ${ }^{13}$ It pointed out that the D.C. Circuit rejected the concept merely because it knew of no authority for such relief. ${ }^{14}$

In Clemens, the Ninth Circuit decided to join the "thoughtful discussion of the Third, Seventh, and the Tenth Circuits and approve the award of tax neutralization to make the plaintiff whole."

Since the Clemens case was limited to past earnings losses, the decision was to award an equitable relief of a "gross up adjustment" to compensate for the increased income-tax liability resulting from a plaintiff's receipt of a back-pay award in one lump sum. However, there is little doubt that had Mr. Clemens sustained future losses, that an application of a tax neutralization would have been approved by the Ninth Circuit for front-pay damages as well, provided that the expert laid a proper and sufficient foundation for his/her opinion.

The term "gross up adjustment" used by the Ninth Circuit is equivalent to the term "tax neutralization" herein. ${ }^{15}$

Given favorable decisions in the Third, Seventh, Ninth, and Tenth Circuits for the application of tax neutralization, economists and financial experts are now free to testify to the amount needed to neutralize the adverse tax consequences in the federal courts of the following 15 states: Delaware, New Jersey, Pennsylvania, Illinois, Indiana, Wisconsin, Alaska, Arizona, California, Hawaii, Idaho, Colorado, Kansas, New Mexico, and Oklahoma.

\section{The Economy Case}

Dr. Kenneth Economy is an anesthesiologist whose hospital privileges were terminated by Sutter East Bay Hospital. The lower court ruled that Sutter was liable for Dr. Economy's past and future damages and, in addition to the economic damages, awarded the tax neutralization amount testified to by the expert. Sutter appealed both the liability and the tax neutralization award.

As regard to the tax neutralization award, Sutter argued that tax neutralization should not have been awarded by the lower court on the ground that it was speculative, primarily because it was calculated by the expert assuming that current tax rates would apply to sequential lost income in the future. ${ }^{16}$ Sutter pointed out that, in California, damages in personal injury and wrongful death cases do not account for taxes on the ground that tax implications are inherently speculative.

The Court of Appeal first pointed out that there is nothing speculative about a tax difference applied to back-pay losses. As to the application of tax neutralization to future losses, the court found that such a calculation was no more speculative than any other projection of future damages. It saw no reason why this factor cannot be established with sufficient certainty.

The Court also distinguished the long tradition in California of not considering taxes in personal injury and wrongful death cases. It pointed out that, unlike a personal injury or a wrongful death case, the purpose of the award of tax neutralization in the present case is to make sure that the plaintiff is fully compensated for his losses, i.e., is made whole.

Sutter did file an appeal to the California Supreme Court, and that Court denied certiorari for an appeal of that decision. Therefore, the decision of the Court of Appeal is final. 


\section{CONCLUSION}

With the Ninth Circuit decision in Clemens and the California Court of Appeal decision in Economy, economic and financial experts in California could now testify to tax neutralization in Ninth Circuit Federal cases as well as California courts. ${ }^{17}$

\section{ENDNOTES}

1. See 20 U.S.C. Section 104(a)(2) and Comm'r v. Schleier (1995) 515 U.S. 323.

2. The legal literature often refers to the tax neutralization as the "tax gross-up."

3. See, for example, Lewis \& Bowles or Ben-Zion, whose papers were published by the year 2000.

4. (E.D. of Pennsylvania, 2000) 108 F. Supp. 2d 443. It should be noted that Judge Jacob P. Hart awarded an additional award to compensate for the adverse tax consequence but did not award the additional funds to neutralize it.

5. See, for example, Polski \& Befort.

6. See, for example, Rodgers and Ireland.

7. The author of this paper has testified in numerous state and federal cases in California and has never been deprived of the opportunity to do so.

8. Arthur Clemens, Jr. v. Century Link, Inc. \& Qwest Corporation (2017)874 F.3d 1113.

9. Kenneth Economy v. Sutter East Bay Hospitals (2019) 31 Cal.App.5th 1147.

10. Linda Blaney v. International Association of Machinists and Aerospace Workers, District No. 160. (2004) $151 \mathrm{Wn} .2 \mathrm{~d} 203$

11. Eshelman v. Agere Sys, Inc. (2009, Third Circuit) 554 F.3d 426.

12. EEOC v. N. Star Hospital, Inc. (2015, Seventh Circuit) 777 F.3d 898.

13. Sears v. Atchison, Topeka \& Santa Fe Ry., Co. (1984 Tenth Circuit) 749 F.2d 1451.

14. Dashnaw v. Penn (1994 D.C. Circuit) 12 F.3d 1112.

15. It is the opinion of this author that the term "Tax Neutralization" is more descriptive than the term "grossup adjustment."

16. The expert economist who testified in this case is the author of this paper.

\section{REFERENCES}

Benich, J.J. (1996). Alternative Approaches to Tax Adjustments in Appraising Economic Loss: Comment. Journal of Legal Economics, 6(2), 91-93.

Ben-Zion, B. (2000). Neutralizing the Adverse Tax Consequences of a Lump-Sum Award in Employment Cases. Journal of Forensic Economics, XIII(3), 233 -244.

Ireland, T.R. (2010). Tax Consequences of Lump Sum Awards in Wrongful Termination Cases. Journal of Legal Economics, 17(1), 51 - 74.

Lewis, W.C., \& Bowles, T.J. (1996). Alternative Approaches to Tax Adjustments in Appraising Economic Loss. Journal of Legal Economics, 6(1), 27 - 38.

Polsky, C.D., \& Befort, S.E. (2004). Employment Discrimination Remedies and Tax Gross Ups. Iowa Law Review, 90(1), 67 -120.

Rodgers, J.D. (2003). Handling Taxes in Employment Cases. Journal of Forensic Economics, XVI(2), $225-256$. 